

\begin{abstract}
Policy-making that re-presents - as objects of concern and by means of statistics - the suffering or depression and the happiness of populations indicates an evolving form of governance that examines and reshapes subjectivity itself. Never before have states of subjectivity been acted upon, through surveys, statistical and policy analysis, and scientific disciplines, to the extent seen today.

This article:

Documents changing epistemic co-ordinates, especially in psychology and economics, that first occluded happiness in the interests of objectivity, but, in recent decades, marked out a renewed 'science' of happiness.

Examines changes in the discursive formulation of depression, as a counterpart to happiness.

Argues that, seen in terms of bio-power, contemporary concerns for happiness and depression are consistent - rather than incompatible - with one another.

How can so many claim to be happy when so many, we are told, are depressed, anxious or suffering emotional pain? There is no underlying contradiction here, for two reasons: Happiness and depression are manifestations of the same political discourse (or aspects of a political subjectivity) characterized by dis-inhibition, consumer self-indulgence and performance anxiety. And, just as we needed madness in order to understand 'sanity,' or the prison in order to view ourselves as 'free,' so we rely upon concerns about depression in order to understand and act upon ourselves as subjects capable of unlimited happiness.
\end{abstract}

Keywords: happiness; depression; biopolitics; human sciences; public policy 


\title{
Happiness, Sadness and Government
}

\author{
G. Duncan
}

\section{Introduction}

Since antiquity, happiness (or eudaimonia) has served a central role in political theory. But, never before have such states of subjectivity been acted upon, by means of surveys, statistical and policy analysis, and scientific disciplines, to the extent seen today. Hence, we may ask, 'Within what epistemic coordinates did a science and a politics of happiness become not only intellectually possible, but convincing, or even necessary?' I address this by observing how the rise of interest in happiness has been associated with perceptual shifts within the disciplines of psychology and economics. Retracing the history of these disciplines reveals an initial 'oblation' of happiness, and of subjectivity in general, in the interests of bringing the human sciences closer to the model of the natural sciences. But, as social-surveying and public-health techniques expanded, the 'inner frontier' of subjectivity has re-appeared before the gaze of these disciplines. Furthermore, the recent politico-scientific concern for happiness arises in tandem with the 'rise' of depression. While positive psychology has sought to go beyond the study of pathology, I argue that contemporary happiness studies and happiness imperatives need to be understood alongside contemporary depression, sadness and suffering.

\section{Be Happy!}

Before we consider an imperative for governments to be concerned about our happiness, we need to ask: Is there a duty to be happy? If there were, it could arise from the following logic: Because you can choose to be happy (by choosing the things that research shows make us happy), and, because we know that happier people are healthier and more productive, then there is an ethically compelling (albeit paradoxical) injunction: 'Be happy.' If you don't feel happy, then it may follow that you failed to practise ethical self-discipline or moderation; and you ought to obey the prescriptions of authorities to deal with your depression.

Furthermore, if there is a personal duty to be happy, does it then follow that there is a socio-political obligation requiring governments to make policy decisions based on whatever (according to research) may be conducive to happiness, if not to educate the people in how to be happier? If we agree to such a governmental obligation, then it could be supported thus: If happiness is a rational and imperative goal for the individual, and if social choices can be derived from surveying and analysing the happiness-maximizing choices of the members of society, then governments must do all they can to maximise happiness. If everyone self-evidently wants happiness, and if everyone can (indeed should) achieve happiness, then everyone ought to vote for and collaborate with a government that persuades us (based on evidence) that it can increase happiness. Not to support such policies - and such politicians - would appear to be irrational, if we adopt the Whiggish logic presented so far. 
A reader trained in critical thinking may already suspect, though, that hidden in this logic there is, for instance, the potential for 'happiness and harmony' to become a slogan of an authoritarian government that 'knows best.' Or she might ask: 'What happens when the majority accuses a transgressive minority of "spoiling our happiness"?' Hence, we should not leap to the conclusion that happiness may be a legitimate object of governmental concern and action.

If it were the case that the subject is enjoined to maximize happiness, however, we must also take account of public-health warnings of a rising epidemic of depression and campaigns that urge the depressed to overcome shame and stigmatization and to seek help. How can more of us be happy, when so many, we are told, are suffering from depression and anxiety? Happiness advocates can argue that the alleviation of mental suffering is a logical and humane 'front' for the happiness-maximization project (Layard, 2005). But, on further examination, I will argue that the etho-political uses of happiness and depression are manifestations of the same political discourse, or political subjectivity, common to an era characterized by dis-inhibition, consumer self-indulgence and performance anxiety; and, just as a knowledge about madness enabled us to perceive sanity (Foucault, 2009), or the prison enabled subjects to see themselves as 'free' (Foucault, 1995), so an awareness of an ever-impending disorder of depression enables us to act upon ourselves as subjects capable of unlimited happiness.

\section{Happiness, utility and economics}

Students of politics will know that affect plays a strong role in the theory of sovereignty and government. The exercise of power is not only 'a set of actions upon other actions' (Foucault, 1982, p. 789); it may also be actions upon the feelings of others. For Hobbes, it is the people's fear of the sovereign that makes the protection of peace and security possible and induces the obligation to obey (Hobbes, 1998). Happiness has little to do with it. Spinoza, in contrast, depicts ambivalent and constantly circulating affects (especially joy and sadness) as constituting the power to act and be acted upon as subjects (Spinoza, 1996).

For Aristotle, though, happiness in its whole-of-life sense was unambiguously the natural aim of the state, at least for those free men who had the leisure and education to aspire to it. And Jeremy Bentham (1748-1832) epitomizes the etho-political use of happiness in the modern era. By nature, he claimed, pain and pleasure rule our actions, determining not only what we feel like doing but also what we ought to do. And, by aggregation and calculation, the 'principle of utility' should apply to the choices made by a society as a whole (Bentham, 1979). Bentham was not the only thinker of his era to ponder how societies might deliberately and effectively maximize human happiness, however, and the principle of utility plays a part in a range of political ideologies of the nineteenth century, from socialism to liberalism, as well as in the evolving theories of economics. William Stanley Jevons (1835-1882) and Francis Edgeworth (1854-1926), key authors of the 'marginal revolution,' developed Bentham's notion of a 'felicific calculus,' drawing it into mathematical analysis, with the aspiration of creating a natural science of economics. 'Felicific calculus' assumes that pain and pleasure are direct opposites on a one-dimensional scale, one pole being negative, the other positive, and that they may be rendered as cardinal values in an algebra that would then combine happiness with economic utility and decision-making. Edgeworth arrived at 'the conception of Man as a pleasure machine,' justifying the use of mechanical terms and mathematical reasoning, even though the machine may be too complex to physically measure:

We cannot count the golden sands of life; we cannot number the 'innumerable smile' of seas of love; but we seem to be capable of observing that there is here a greater, there a less, multitude of pleasure-units, mass of happiness; and that is enough (Edgeworth, 2003, p. 481).

Aside, however, from the problem that (as Freud (1997) observed) pain and pleasure are not always in 
direct opposition to one another, the utilitarians were unable to prove that there are means for measuring and summing the happiness of a community in a way that is inter-subjectively comparable. Vilfredo Pareto (1848-1923) is credited with proving that utility cannot be measured or interpersonally compared, and cannot be quantified from observed behaviors. Subsequently, economists such as Sir John Hicks (1904-1989) accepted that the old concept of cardinal utility (or happiness) had to be replaced by an ordinal 'scale of preferences,' thus extending the applicability of economic methods to a wider scope of human behaviors 'by transforming the subjective theory of value into a general logic of choice' (Hicks \& Allen, 1934, pp. 52, 54).

The early decades of the twentieth century saw efforts to remove all subjective factors from economics, and to develop a scientific method that would rely only upon that which is directly observable. This was partly influenced by behaviorism (see below). As Lionel Robbins (1898-1984) pointed out, however, a thoroughgoing objectivism was not possible, as economists would at times appeal to psychological matters that are not open to observation. For instance, 'the most elementary process of price determination must depend inter alia upon what people think is going to happen to prices in the future' (Robbins, 2008, p. 85; originally published 1935). Nevertheless, to lend the emerging discipline of economics the kind of authority associated with the natural sciences, feelings or motives such as happiness, pain or pleasure were eliminated from the notion of economic utility. The latter was reduced to the observable decisions of consumers in a market. The individual's behavior, faced with variable choices, reveals a 'preference pattern' and hence:

The whole theory of consumer's behaviour can [...] be based upon operationally meaningful foundations in terms of revealed preference (Samuelson, 1948, p. 251).

This can be measured in prices, and summed to provide macroeconomic statistics such as gross domestic product (GDP). The inner feelings or motives, the psychological 'investments', 'incomes' or 'losses' of the subject were left untouched in their unmeasurable 'black box,' and there emerged a homo oeconomicus, a mere demand function and an inscrutable locus of volumes of commodities exchanged at quantifiable prices. Bentham's principle of utility thus yielded to:

[...] a rigorous utilitarian ethic in which what 'revealed preferences' revealed was the degree of utility derived from consumption, not the degree of happiness (Tribe, 2008, p. 465).

\section{Happiness and psychology}

This did not mean, however, that happiness was consigned to the realm of psychology, as it too was striving to emulate the natural sciences. Academic psychology, especially in the United States, came to be dominated by behaviorism, an objectivist approach that rigorously rejected the introspective techniques of earlier pragmatist philosophers such as William James (1842-1910) and the psycho-dynamics of Sigmund Freud (18561939). The behaviorism of John B. Watson (1878-1958) sought to create a purely experimental psychology, the aim of which would be 'the prediction and control of behavior':

This suggested elimination of states of consciousness as the objects of investigation will remove the barrier that exists between psychology and other natural sciences [... ] (Watson, 1913, p. 158).

The experimental methods of operant conditioning, developed later by B.F. Skinner (1904-1990), took the observed environmental rewards and punishments affecting the organism and measured the consequent patterns of behavioral output. If learning and behavior are always the products of environmental conditioning, then the external 
rewards and punishments need to be more carefully arranged, to ensure the survival of society. Ideals of liberty or happiness only aggrandize the individual rather than secure the future of a culture (Skinner, 1971). Introspective or psychoanalytical approaches were marginalized from psychology departments, and students were trained in experimental methodology.

Psychoanalysis continued to be practiced, but, for quite different reasons, it too did not provide encouragement for a positive science or ethics of happiness. Freud assumed that the inner conflict between aggressive and erotic drives inevitably causes neurosis, and so the best we can hope for is a psychic compromise between the reality and pleasure principles (Freud, 1985). The medical specialism of psychiatry too was focused more on psychopathologies and their classification than on maximizing the potential for positive mental health. The discoveries of electro-convulsive therapy and anti-psychotic drugs raised hopes for the emergence of new techniques that would cure insanity without the need for lengthy talking-therapy or unscientific ideas such as the unconscious (Ehrenberg, 2010).

\section{Happiness Redux}

So, to understand why the recent return to happiness in the fields of psychology, economics and public policy appears to some contemporary authors to be 'revolutionary' (Frey, 2008), we need to take account of the movement in the twentieth century towards treating the human sciences as if they were natural sciences, shifting them away from anything that could not be objectively observed and measured. Happiness fell outside of the horizons of these disciplines. How, then, did happiness find its way back in? In this section, I outline two main avenues: the first was through critiques of the social-psychological consequences of affluence that emerged from within the profession of economics; and the second was via a humanistic psychology that arose partly in reaction to the reductionism of experimental psychology.

Among economists, a critique of revealed preference and GDP as proxies for utility began in the 1970s. Tibor Scitovsky's The Joyless Economy questioned the effects on human well-being of economic affluence and a consumer society that created comfort and left many people with no real survival challenges and little aspiration to higher cultural achievements. He did not advocate a return to Bentham's one-dimensional view of pain and pleasure. The accumulation of goods may create comfort, but Scitovsky distinguished this from pleasure. Pleasure is not so much a mental state or sensation as a process of change from too much or too little stimulation back to an optimal level. Pleasure, then, depends upon some level of displeasure or dissatisfaction that can motivate the person to achieve change (Scitovsky, 1976). The comfort derived from material affluence brought with it the potential loss of contact with the true sources of pleasure and happiness, according to this critique. Of more direct significance for happiness research in economics, though, were the findings of Richard Easterlin. A long series of American public surveys showed no apparent rise in happiness or life-satisfaction in spite of strong economic growth since the end of World War II (Easterlin, 1974). This was dubbed 'the Easterlin paradox,' as economists puzzled over why growth in real incomes and consumption should not also augment the subjective happiness 'variable' that had been bracketed out of their calculations half a century earlier. Since Easterlin's seminal paper, happiness research in economics, although not universally adopted into the discipline, has blossomed. It is now argued, based upon surveys conducted world-wide, that happiness is a valid and universally recognised construct that is reliably measurable and empirically robust: 
A subjective view of utility recognizes that everybody has their own ideas about happiness and the good life and that observed behavior is an incomplete indicator for individual well-being. Nevertheless, individuals' happiness can be captured and analyzed: people can be asked how satisfied they are with their lives (Frey \& Stutzer, 2002, p. 405).

In effect, happiness has re-entered the field of economics as a subjective quality defining utility. And there is now, it is claimed, a 'new utilitarianism' (Veenhoven, 2004) or a 'new science' of happiness (Layard, 2005) that can address our personal and political choices. Hence, non-material and subjective factors need to be measured if nations are to give a fuller account of their progress and collective well-being.

The formative techniques for the study of subjective well-being and happiness are the public-opinion survey and randomized stratified sampling. Consumer surveys and public opinion-polls, often by telephone, have become ubiquitous practices that serve a range of aims, such as marketing, social research and political analysis. Being called by pollsters or researchers for one's opinion has become a norm, despite 'resistance' from subjects who do not respond or 'don't know.' The social survey or opinion poll aids reflexively to form respondents as subjects in possession of pre-existing opinions, preferences and feelings, despite the 'opinionless' minorities (Peer, 1992). Mirroring the democratic rationality of 'one person, one vote', the poll assumes that each person has (or ought to express) an opinion, and that each person's opinion (or happiness) is equally valid. A paedophile's happiness has statistical value equal to the child's.

The claim to authority of the social survey is based on statistical rigor and on the assumption that the 'conditions' being surveyed pre-exist the survey and the concerns that motivate it. They must be considered objectively 'out there', waiting passively to be measured, and not discursively reformulated by the surveying practices and media coverage as forces that, by identifying and objectifying them, reveal them to the public field of vision. Although subjective, happiness is seen as universal, empirically valid and self-evidently good, and so the survey-data on happiness should unproblematically re-present happiness per se (Veenhoven, 2004). Some economists have been more cautious, however. Governments may have an incentive to manipulate or reinterpret happiness indicators to suit their own goals; and survey respondents may misrepresent their happiness levels in order to support or undermine current policies (Frey \& Stutzer, 2009). More research and talk of happiness as a social issue in the media and in political debate may reshape our self-awareness as subjects seeking or deserving happiness as a public value, and this could diminish the surveys' validity. Nonetheless, although the use of social surveys to estimate aggregate happiness is not universally accepted by economists, those who do use happiness as a variable assume that the old problem of the measurability and comparability of happiness has been solved (Veenhoven, 2004). Bentham is back, but now he's armed with data.

Similar to the dissatisfaction with economic theory of the consumer, there was a reaction within the discipline of psychology against the objectivism of behaviorist experimental research and against the pessimism and the focus on pathology in psychoanalysis, clinical psychology and psychiatry. Counter-trends such as anti-psychiatry (Szasz, 1960; Laing, 1960) and humanistic psychology (Maslow, 1943; Rogers, 1947) had emerged well before the cultural upheaval of the late 1960s lent them a wider following. These authors drew on philosophies such as existentialism and phenomenology that offered alternatives to, and were critical of, the desire to emulate the natural sciences. Happiness was not always at the centre of these critical alternatives, however, as they originate in traditions that are relatively pessimistic, if not (as in existentialism) hostile to happiness as an aim in life.

One influential instance in which happiness does appear, though, is Maslow's need theory of motivation. Abraham Maslow (1908-1970) introduced the subjective notion of 'need' into the theory of motivation, challenging behaviorism's environmental learning theory. His 'hierarchy of needs' (routinely used in introductory psychology and management textbooks) placed 'self-actualization' at its pinnacle: 
Even if [...] more basic needs are satisfied, we may still often (if not always) expect that a new discontent and restlessness will soon develop, unless the individual is doing what he is fitted for. A musician must make music, an artist must paint, a poet must write, if he is to be ultimately happy. What a man can be, he must be.

This need we may call self-actualization (Maslow, 1943, p. 382).

Reversing Kant's categorical imperative ('you can because you must'), Maslow tells us: 'you can therefore you must.' Rather than regard selfless duty as a sublime burden that enjoins me to strive, Maslow elevates happiness to the condition that turns a supposedly inherent creativity into a necessity of self-fulfilment. This rests on tautology, however: 'a musician must make music' is no more logically or ethically compelling than 'a cow must do the things that cows do.' Nonetheless, according to the ubiquitous Maslow, if all other, more basic needs are met, selfactualization and happiness become our ultimate self-inscribed duties, and to aim for less would deny a creative inner essence. Happiness is thus the ultimate duty of an affluent humanity.

The strongest discursive vector of happiness in contemporary psychology, however, is the 'positive psychology' that emerged in the late 1990s. Positive psychology looks beyond the 'abnormal' and beyond 'mental illness,' towards fulfilment and happiness:

[Psychology's] almost exclusive attention to pathology neglects the fulfilled individual and the thriving community $[\ldots .$.$] We believe that a psychology of positive human functioning will arise that achieves a$ scientific understanding and effective interventions to build thriving in individuals, families, and communities (Seligman \& Csikszentmihalyi, 2000, pp. 5, 13).

Positive psychology has a somewhat fraught relationship with its elder disciplinary cousin, humanistic psychology, however (Waterman, 2013). The latter retains roots in the more pessimistic Continental traditions of Kant, Nietzsche and Sartre; whereas positive psychology is avowedly Aristotelian and pragmatic. Moreover, positive psychology places less emphasis on happiness, if defined hedonically as 'feeling good,' compared to its utilitarian usage among economists. The virtue-ethics inherited from Aristotle mean that positive psychology promotes a range of lived values, such as flourishing, meaningfulness, or gratitude, and happiness enjoys a prominent, but not over-arching, role among them (Jorgensen \& Nafstad, 2004). As it emerges within the empiricist tradition of academic psychology, however, positive psychology prefers quantitative and statistical methods, compared with the preference for qualitative methods in the humanistic tradition (Waterman, 2013). Psychology, then, has readopted happiness as an object of research, even though the contribution of positive psychology, as a branch of the wider discipline, remains contested.

\section{Happiness and Public Policy}

This brief survey, then, has indicated some key shifts within the human sciences that excluded happiness as an object of concern because of its resistance to scientific perception, and later reintroduced it, thanks largely to social-survey and statistical techniques. The return to happiness in economics and psychology has also had effects upon public policy. If rising affluence has had little or no positive effects on the happiness or well-being of communities, then (assuming that happiness is a self-evident, universal goal) it perhaps falls to governments to reconsider their aims. Researchers began to argue that improvement in levels of happiness can, indeed should, become the goal of public policy (Easterlin, 2003; $\mathrm{Ng} \& \mathrm{Ho}, 2006$ ). And various policy recommendations have been 
offered by researchers, such as the regulation of working-hours and safety, minimum-wage and income-support policies, work-life balance, universal health-care and pensions, improved child-care and public education (Dutt \& Radcliff, 2009; Bok, 2010). Welfare-state policies have sometimes been favored by the results of cross-national comparisons of subjective well-being:

Subjective evaluation of life quality is positively affected by governments of the Left. It is also enhanced by the extent to which states reduce market dependency through decommodification of labor and, in general, adopt a social democratic welfare regime (Radcliff, 2001, p. 947).

Of course, there is conflicting evidence and analysis on the extent to which politics (and especially leftist policies) matter to individuals' happiness (Ridge, Rice, \& Cherry, 2009). Traditionally, advocates of social rights, from Thomas Paine (1737-1809) to Sir William Beveridge (1879-1963), have used the ideal of the happiness of the people at large as a teleological justification for reforms, well before the contemporary happiness movement. Happiness researchers now argue that they are providing robust, evidence-based reasons for governments to design policies that can maximize happiness. But are they betraying a left-wing political bias? Frey (2008) suggests instead that democratic institutions and participatory political processes can contribute to aggregate happiness, aside from particular policy prescriptions. But he also suggests placing restrictions on TV advertising and on geographical mobility. Underpinning Frey's case is the finding that people often 'mispredict' the utility or happiness that they will derive from higher incomes, new jobs or new possessions. This is one step away from saying that we don't always know what's good for us, and that certain behaviors need to be more regulated and others encouraged. Libertarians, by contrast, may well be concerned about individual happiness, but they do not welcome strengthened government programs or regulations to promote it (Norberg, 2005). In any case, happiness research results can only offer evidence, which in itself may be disputed; while the politics and social policies remain matters for contested decision-making and public debate. A benevolent, research-informed dictator who knows what will make us happier is unlikely ever to appear, but the specter of such a leader stalks around off-stage.

This brief discussion of the implications of happiness research for social policy leads to the question of how much influence this literature may actually be having on governments. While we have not witnessed anywhere the creation of a 'Ministry of Happiness' (which could have an Orwellian ring to it), happiness discourse is having some effect on the goals and priorities of policy-makers. In the UK, the Blair government commissioned a study on lifesatisfaction (Donovan \& Halpern, 2002); and the subsequent conservative Prime Minister, David Cameron, announced that 'there is a link between what politics and government does and people's happiness, contentedness and quality of life' (Cameron, 2010). This was a prelude to the national statistician's adoption of a broader range of indicators to monitor social progress (broader, that is, than macroeconomic statistics such as GDP); and it reflects what has become an international orthodoxy, as in the OECD's on-line 'Your Better Life Index '1 and the UN's World Happiness Report (Helliwell, Layard, \& Sachs, 2012). The UN proclaimed 20 March to be International Day of Happiness, and the Secretary-General commented:

Social, economic and environmental well-being are indivisible. Together they define gross global happiness (Secretary-General of the United Nations, 2013).

\footnotetext{
${ }^{1}$ http://www.oecdbetterlifeindex.org/
} 
Not all authors agree, however, that there is a convincing case for happiness to be an aim or criterion of public policy (Duncan, 2010; Martin, 2012), even though there are well-established reasons for critiquing the narrow usage of GDP as an indicator of social progress or successful policies (Daly, 1996; Waring, 1989). There can be little doubt, though, that happiness-maximization now claims to be empirically verifiable due to the results of social surveying, and to be above ideology due to its appeal to many conservatives and social democrats. Such dual claims to scientific objectivity and value-neutrality, however, must be treated with caution, as similar claims have been used before by economists to justify a statistical-technocratic approach to the neo-liberal policy agenda and thus to side-step public deliberation. Happiness as a political value needs to be examined politically (Duncan, 2007). And, while happiness surveys produce statistics, they do not produce an object of scientific observation. This is so simply because happiness - defined as either feeling good or living well - is inherently a normative (and non-empirical) judgement about 'the good' that methodologically confounds any observation claiming a scientific status.

We should delve more deeply than the ideological or rational-scientific discourse, however, to reveal happiness on a bio-political front. That is, happiness as a desired subjective state presents a norm around which individual conduct can be shaped; and as a presupposed common value it may be used to regulate communities. To understand further how a 'politics of happiness' acts upon subjectivity, moreover, we can consider sadness or depression. Depression may feel like the opposite of happiness; but, in bio-political terms, it is a close counterpart. And the practices that have sustained its emergence as an epidemic throw light upon the 'political subjectivity' of these times.

\section{The Rise of Depression}

Happiness researchers may argue that, far from neglecting mental illness, they would put the alleviation of such suffering high on the list of political priorities as one of the most effective means to maximize aggregate happiness (Layard, 2005; Bok, 2010). We may look more closely, however, at changes in the discursive formulation of depression in particular, as a counterpoint to happiness, and hence as a way of understanding the political rationality of the contemporary concern with subjective or affective states in general.

Depression, as a term denoting mental suffering, has not always been with us, and it has had to extract itself from the much more ancient melancholia. The latter had been used in many different ways over the centuries, and thus had conflicting associations. Around the turn of the twentieth century, following the influence of Emil Kraepelin (1856-1926) and Adolf Meyer (1866-1950), depression became the preferred term, as psychiatrists sought to develop a unified psycho-biological theory. ${ }^{2}$ This would situate psychiatry as a sub-discipline of medical science and distance it from Freudian theory (Lewis, 1934). There is still much debate about causes of depression (for instance, whether it is due to endogenous biological factors, or external events), about whether there are different kinds of depression due to different causes or patterns of illness or whether it is a single disorder manifesting in various ways, about how it should be diagnosed and how best to treat it (Parker, 2000). These debates are too complex to summarize here, but we should note two matters: first, that the diagnostic practices accepted today, as in the DSM-IV, are based upon subjective, self-reported symptoms, such as mood, insomnia, fatigue; and secondly that the boundary between what is considered 'normal' and what should be diagnosed as 'disordered' is

\footnotetext{
${ }^{2}$ Melancholia continues to be in use in contemporary psychiatric literature, but only in order to distinguish classes of depression (Parker, 2000).
} 
controversial and ever-changing. For instance, a contemporary debate has raged over the removal of 'the bereavement exception' from the diagnostic criteria of depression in the DSM-V (Maj, 2012; Wakefield \& First, 2012). Hence, clinical depression is the product of discursive practices that create and re-create the very 'object' of which they speak.

According to the WHO, moreover, depression is the world's leading cause of years lost due to disability. This was estimated by extrapolating the number of incident cases of depression in a year, multiplying by the average duration of the disease, and then multiplying by a weighting factor that reflects the severity of the disease. The weighting factor is inevitably imprecise, though, as the severity of depression is highly variable. Many people continue to function with depression, some are completely immobilised. Depression drops to third ranking on the scale of disability-adjusted life-years, however, as this latter measure includes the effect of mortality rates. Overall, the prevalence of depression is said to be rising (World Health Organization (WHO), 2008).

Critical questions have been posed about such prevalence and disability statistics and about the underlying clinical definition and diagnosis of depression, even by authorities within the profession of psychiatry itself:

Because they fail to distinguish normal sadness from depressive disorder, and because nondisordered individuals are less likely to seek treatment, population surveys make it seem as if only a minority of disordered people are treated for their conditions. This has led social policies to focus on the presumed vast amount of unmet need for treatment. These policies now emphasize widespread screening for depression among people who have not voluntarily sought treatment. Screening instruments likely uncover more normal sadness than depressive disorder but treat both conditions as if they were disorders (Horwitz \& Wakefield, 2007, p. 21).

The supposed growth of depression may thus be an artefact of evolving diagnostic practices and widening boundaries - although the above statement assumes that somewhere there exists a 'truer' normal-disordered boundary. Moreover, there is a literature inquiring critically into the results of the randomized clinical trials used to validate new anti-depressants (Whitaker, 2010), and into the practices and motives of the researchers and of the manufacturers and marketers of psychoactive drugs (Angell, 2011a,b). It is beyond the scope of the present article to address these questions in depth, but it is important to acknowledge that this lively contemporary debate places the definition, diagnosis and treatment of depression into question.

The insights of Foucault into the birth of the asylum and the attendant disciplines and 'dividing practices' (Foucault, 2009) give cause to reflect more profoundly upon the growth of the medical profession of psychiatry and the management of the population of melancholics, or latterly 'the depressed.' The shifting delineations of madness cannot be separated from historical changes in institutional structures, the rise of psychiatric care and the treatment of the mad as objects of medical knowledge. Contemporary neo-liberal policy, however, is critical of public institutions, favors care in the community, and has led to the disestablishment of many psychiatric hospitals. In this post-asylum era, care of depression is largely pharmacological and physically unconfined, but also increasingly 'normalized' in that now large proportions of society are said to require and benefit from it. Prominent personalities publicly 'confess' that they suffer from it in order to encourage others 'to come forward.' And many people undoubtedly do suffer emotionally or mentally. But, just as 'the birth of asylum' accompanied a new relationship between madness and the self-knowledge that would unfold within the psychological disciplines, so the demise of the asylum (or 'deinstitutionalization') in the late twentieth century is attended by a further change in the relationships between madness, knowledge and practices of care.

The specific practices that formed the 'depression' we are now acquainted with are numerous, and they include: the rise, and in recent years the disestablishment, of the asylum as an enclosed institutional space for the 
treatment and confinement of the mentally ill; the development of physical therapies, including electro-convulsive therapy and the progressive development of drugs; the sometimes competing techniques of 'talking' psychotherapies and self-help; the social movements that have identified and combated stigmatization and discrimination; problems of crime and 'dangerousness'; the search for flexibility in labor-forces and maximization of labor-force participation, including the mentally ill; the characterization of employment as 'therapeutic'; and the capacities of health services as they have shifted persons under treatment out of the asylum and into 'normal' accommodation. Depression has formed itself as an object of concern within a complex developing field of practices (Ehrenberg, 2010; Iliopoulos, 2012; Philip, 2009).

Depression (or the depressed subject) emerges within a moral economy that continually shapes and reshapes the reciprocal obligations to act, to treat, to support, and to work in social and institutional settings. As an example of this reshaping of mutual obligations over time, consider John Keats as he wrote his 'Ode to a Nightingale' in 1819, expressing deep sorrow, loss of energy and a desire to die. In today's out-patient clinic, this would indicate a Major Depressive Episode - and not the sublime melancholia of poetic genius. Having used his own words to screen him into a treatment programme, he could be prescribed medication and referred for cognitivebehavior therapy. In his time, such health services were not yet invented, but today many would insist upon them as a matter of individual rights and well-being. So the very availability of those services has reflexively shaped our perceptions and understandings of the depressed/melancholic subject and of the obligations owed by others. To say, for instance, 'she had to go on anti-depressants' becomes an explanation (however poorly examined) for a problem of subjectivity, based upon a supposed therapeutic solution. We are encouraged to lift the stigma from depression and to seek help for it; and hence its revelation in the privacy of the clinic, followed by care and prescribed drugs as 'goods', form a productive cycle of exchanges.

\section{Melancholic calculus}

The Centre for Economic Performance of the London School of Economics in its 'New Deal for Depression and Anxiety Disorder' illustrated the kind of economic calculation into which this form of suffering can be entered as a factor. Depression and anxiety disorders are characterized by this Report as 'the great submerged problem, which shame keeps out of sight' (Centre for Economic Performance (CEP), 2006, p. 1; italics added). It was estimated that one sixth of the adult British population suffer from depression or anxiety disorder. The Report cites evidence that half of those who suffer depression or anxiety disorder experience sustained relief after a course of cognitive behavior therapy (CBT), and for every twelve months 'free of depression' it calculates a gain of 'nearly two months more of work' (CEP, 2006, p. 6). So, a calculable cost of such suffering arises from the detachment of workers from economically productive labor; and the value of relieving it can be weighed in units of economically productive time. The Report estimates, however, that only one in four of those who fall out of their work routines due to feeling bad receive treatment. The cost of mass CBT is outweighed, it is argued, by the costs of lost productivity, lost taxes and social expenditure. The recommended solution then is simple: with the aim of treating 800,000 people per year, the British government should implement a 'centrally-led and centrally-funded' plan to train 10,000 new psychotherapists (CEP, 2006). It is assumed that those who suffer depression and anxiety will 'voluntarily' overcome their 'shame' in order to express or confess their suffering to their health-care providers in the context of the clinic.

Depression is thus said to be both largely hidden and on the rise in the world; it acts as both a brake upon and an opportunity for productive work, as it stimulates a form of 'affective labor' (Hardt, 1999). The more that depression is seen to be an epidemic that is 'hidden' due to shame and stigma, the greater the biopolitical rationale for influencing public opinion in favor of wider provision of pharmaceuticals and psychotherapy. One is therefore enjoined to confess oneself as depressed in the context of the clinic. Revelation of this hidden suffering is also a 
claim for care and for temporary exemption from the obligation to work. It supplies immaterial 'goods' for forms of affective labor, supported by public-health initiatives that aim to increase treatment rates by surveying and changing public attitudes towards depression and towards anti-depressant drugs (Paykel, Hart, \& Priest, 1998; Dietrich, Mergl, Freudenberg, Althaus, \& Hegerl, 2010; Pratt, Brody, \& Gu, 2011). The profession of psychiatry has become a publicly subsidized research and development, marketing and advertising agent for the pharmaceutical industry.

\section{Depression as poor performance}

Depression represents a detachment from the labor-force by workers who have been immobilized by psychological suffering. Indeed, it may be characterized as the signature form of disability for a post-industrial economy:

Depression is just sheer incapacity, a distinctly neo-liberal form of psychological deficiency, representing the flipside of an ethos that implores individuals to act, enjoy, perform, create, achieve and maximize. In an economy based in large part on services, enthusiasm, dynamism and optimism are vital workplace resources. The depressed employee is stricken by a chronic deflation of these psycho-economic capacities, which can lead him or her to feel economically useless, and consequently more depressed (Davies, 2011, p. 67).

A neo-liberal economy, inhabited by subjects interpellated as autonomous individuals competing in a market of immaterial labor, experiences rising depression as an 'affective incapacity' that flows into the health-care industry.

Depression [...] is melancholia plus equality, the perfect disorder of the democratic human being. It is the inexorable counterpart of the human being who is her/his own sovereign. We are not speaking of the human being who has acted badly but, rather, of the human being who cannot act. Depression is not conceived in terms of law, what is allowed and what is forbidden, but in terms of capacity (Ehrenberg, 2010, p. 219; original italics).

Neurosis, born of our constitutive inner conflicts, was the psychopathology of an age dominated by obedience and law, an age that demanded and normalized the inhibition of desire; whereas inadequacy or incapacity to act, and hence depression, constitute the pathology of the neo-liberal age which values performance and consumption and hence the disinhibition of one's desires, capacities and energy. In a world in which it is imperative to be performing at ever-higher levels of efficiency and excellence, to be 'on call' and striving to achieve one's best, to be aspirational, self-transforming, and author of one's own life-narrative, depression becomes the signature pathology, the affective incapacity for life-as-expected. And the role of the 'anti-depressant' drug is not so much to cure an illness as to overcome an inability to act (Ehrenberg, 2010).

No longer is it a matter of madness and reason - opposing yet interdependent terms. Depression, as a clinically recognizable condition, blends indistinctly into the common daily sufferings of free subjects. It exploits the indefinite nature of the normal-abnormal boundary, and contributes to the transformation of psychiatry from institutionally confined disciplinarity into an ambulatory biopolitical practice that stimulates productive industries. These new affective industries seek to enhance the performance of the 'disordered' subject by releasing the 'handbrake' that was seized by the fear that one cannot measure up or perform. 


\section{Conclusion}

Augmenting Ehrenberg's conclusion that depression is 'the inexorable counterpart of the human being who is her/his own sovereign' (Ehrenberg, 2010, p. 219), I argue that depression is also the counterpart of the autonomous human being who is supposed to be capable of unlimited happiness, and hence whose duty is to perform and be happy. Contemporary concerns for happiness and depression are consistent - rather than incompatible - with one another in that they operate upon the same broad bio-political front of performativity, or the augmentation of the subject's capacities to enjoy, to produce and to act prudentially. But depression is not only about what a body can or cannot do. It is also about what it can or cannot feel. It poses the problem of how to act upon the depressed subject in order that he/she should feel good, or be happy.

We have traced, then, ensembles of professional-disciplinary practices and scientific perception that, in the late nineteenth and early twentieth centuries, erased almost all trace of a subjectivity that could feel happiness and sadness, as if the subject didn't exist; but then, from the latter decades of the twentieth century, marked them out again as positive 'objects' to be submitted to a scientific authority and verification. Psychology and economics thus initially reduced the figure of the human to a laboring, choosing, and learning body, emptied of will, thought or emotion. Then latterly they returned to address a fuller, but nonetheless quantifiable, image of a human being that can, after all, feel pain, pleasure, happiness and sadness; and they delivered this subject up to a governmental rationality that seeks to measure and to act upon those feelings. All in keeping with their efforts to emulate the natural sciences, psychology and economics have undergone a double movement by which what was once said to be unknowable could at last be accounted for scientifically by means of statistics. The unseen subject was first removed from their concerns in the interests of measurement, prediction and control of bodies and goods. This unseen has since been rehabilitated, regarded now as measurable and treatable, if only the subject will reveal an inner being by speaking of his/her pain, suffering, depression, satisfaction or happiness. And a new ethical and economic government of the subject - a political subjectivity - relies upon this newly demarcated 'reality.' In an economy based upon immaterial labor and enhanced performance, happiness counts. As an ethical and political goal, happiness is rationalized on the grounds that it is a self-evident and universal good, positively related to a range of life-enhancing factors. The present analysis regards the 'science' and politics of happiness as belonging to the entry of psychic life into history, an expansion of a political intervention into life itself that sees its aim as the maximization of the potentials of individuals and the productivity of populations. It is an aspect of a bio-power reflected back upon itself, as if the subject that knows should be the simple mirror-image of the subject that is known. ${ }^{3}$

Policy-making that re-presents, as objects of concern and by means of statistics, the suffering or depression and the happiness of populations indicates an evolving form of governance that examines and reshapes subjectivity itself. Just as it took the discovery in the eighteenth century of a political economy - distinct from household regulation - to give rise, with the assistance of statistics, to a government of the industrial age, so we are witnessing a political subjectivity wherein the (supposedly private) field of the psyche expands to form a frontier for publicpolicy technology. The desire to stabilize, naturalize and individualize the potentials and the pathologies of each member of the polis requires a political subject that is treated as a function of utility. This ideal subjectivity,

\footnotetext{
${ }^{3}$ The human 'must be a positive domain of knowledge and cannot be an object of science' (Foucault, 1994, p. 367).
} 
'liberated' from sadness and 'free' to be happy, is thus subject to a power that acts upon the capacities of bodies to act and to feel. ${ }^{4}$

The disciplines of political economy (or economics) and psychology have shifted their borders accordingly, but this does not mean that those disciplines have abandoned their project of presenting human sciences as if they were natural sciences. To the contrary, the subjectivities of happiness and sadness become the statistical objects of new fields of 'human sciences' that have striven, and yet found it impossible, to be sciences. Nevertheless, the epistemic authority of scientific practice, set out in statistics, is coupled with the capacities to act upon populations and individuals that extend throughout the apparatuses of the state, with the aim of optimising how the subject may feel.

\section{References}

Angell, M. (2011a, June 23). The epidemic of mental illness: Why? Retrieved March 16, 2012, from The New York Review of Books: http://www.nybooks.com/articles/archives/2011/jun/23/epidemic-mental-illness-why/

Angell, M. (2011b, July 14). The illusions of psychiatry. Retrieved March 16, 2012, from The New York Review of Books: http://www.nybooks.com/articles/archives/2011/jul/14/illusions-of-psychiatry/

Bentham, J. (1979). Introduction to the principles of morals and legislation (chapters I-V). In M. Warnock, Utilitarianism (pp. 33-77). Glasgow: Fount.

Bok, D. (2010). The politics of happiness: What government can learn from the new research on well-being. Princeton: Princeton University Press.

Cameron, D. (2010, November 25). PM speech on wellbeing. Retrieved November 8, 2011, from UK Prime Minister's Office: http://www.number10.gov.uk/news/pm-speech-on-well-being/

Centre for Economic Performance (2006). The depression report: A New Deal for depression and anxiety disorders. London: London School of Economics and Political Science.

Daly, H. (1996). Beyond growth: The economics of sustainable development. Boston: Beacon Press.

Davies,W. (2011).The political economy of unhappiness. New Left Review (71), 65-80: http://newleftreview.org/II/71/william-davies-the-political-economy-of-unhappiness

Dietrich, S., Mergl, R., Freudenberg, P., Althaus, D., \& Hegerl, U. (2010). Impact of a campaign on the public's attitudes towards depression. Health Education Research, 25 (1), 135-150. doi:10.1093/her/cyp050

Donovan, N., \& Halpern, D. (2002). Life-satisfaction: The state of knowledge and the implications for governments. London: Strategy Unit.

Duncan, G. (2007). After happiness. Journal of Political Ideologies, 12 (1), 85-108. doi: $10.1080 / 13569310601095630$

\footnotetext{
${ }^{4}$ This points towards the scope for affect theory (e.g.: Ruddick, 2010; Williams, 2010) to add further corrective
} and critical responses to this analysis of political subjectivity. 
Duncan, G. (2010). Should happiness-maximization be the goal of government? Journal of Happiness Studies, 11 (2), 163-178. doi: 10.1007/s10902-008-9129-y

Dutt, A. K., \& Radcliff, B. (2009). What is to be done? Toward a 'happier' world. In A. K. Dutt, \& B. Radcliff, Happiness, economics and politics: Towards a multi-disciplinary approach (pp. 343-350). Cheltenham: Edward Elgar.

Easterlin, R. A. (1974). Does economic growth improve the human lot? Some empirical evidence. In I. David, \& M. Reder, Nations and households in economic growth. Essays in honor of Moses Abramovitz (pp. 89-125). New York: Academic Press.

Easterlin, R. A. (2003). Explaining happiness. Proceedings of the National Academy of Sciences of the United States of America, 100 (19), 11176-11183. doi:10.1073/pnas.1633144100

Edgeworth, F. Y. (2003). Mathematical psychics (1881). In S. G. Medema, \& W. J. Samuels, The history of economic thought: A reader (pp. 479-503). London: Routledge.

Ehrenberg, A. (2010). The weariness of the self: Diagnosing the history of depression in the contemporary age. Montreal: McGill-Queen's University Press.

Foucault, M. (1995). Discipline and punish: The birth of the prison. New York: Vintage Books.

Foucault, M. (2009). History of madness. London: Routledge.

Foucault, M. (1994). The order of things: An archaeology of the human sciences. New York: Vintage.

Foucault, M. (1982). The subject and power. Critical Inquiry, 8 (4), 777-795.

Freud, S. (1985). Civilization and its discontents (1930). In S. Freud, Society and religion: Pelican Freud library (Vol. 12, pp. 245-340). Harmondsworth: Penguin.

Freud, S. (1977). Three essays on the theory of sexuality (1905). In S. Freud, On sexuality: Pelican Freud library (Vol. 7, pp. 31-169). Harmondsworth: Penguin.

Frey, B. S. (2008). Happiness: A revolution in economics. Cambridge MA: MIT Press.

Frey, B. S., \& Stutzer, A. (2009). Should national happiness be maximized? In A. K. Dutt, \& B. Radcliff, Happiness, economics and politics: Towards a multi-disciplinary approach (pp. 301-323). Cheltenham: Edward Elgar.

Frey, B. S., \& Stutzer, A. (2002). What can economists learn from happiness research? Journal of Economic Literature, 40, 402-435.

Hardt, M. (1999). Affective labour. Boundary 2, 26 (2), 89-100.

Helliwell, J., Layard, R., \& Sachs, J. (2012). World happiness report. New York: The Earth Institute, Columbia University.

Hicks, J., \& Allen, R. (1934). A reconsideration of the theory of value. Economica, 1 (1), 52-76.

Hobbes, T. (1998). Leviathan. Oxford: Oxford University Press.

Horwitz, A., \& Wakefield, J. (2007). The loss of sadness: How psychiatry transformed normal sorrow into depressive disorder. New York: Oxford Univeristy Press. 
Iliopoulos, J. (2012). Foucault's notion of power and current psychiatric practice. Philosophy, Psychiatry, \& Psychology, 19 (1), 49-58. doi: 10.1353/ppp.2012.0006

Jorgensen, I., \& Nafstad, H. (2004). Positive psychology: Historical, philosophical and epistemological perspectives. In L. P.A., \& S. Joseph, Positive psychology in practice (pp. 15-34). Hoboken: John Wiley.

Laing, R. (1960). The divided self: An existential study in sanity and madness. Harmondsworth: Penguin.

Layard, R. (2005). Happiness: Lessons from a new science. New York: Penguin.

Lewis, A. J. (1934). Melancholia: A historical review. The Journal of Mental Science, 80 (328), 1-42.

Maj, M. (2012). Bereavement-related depression in the DSM-5 and ICD-11. World Psychiarty, 11 (1), 1-2.

Martin, M. W. (2012). Happiness and the good life. Oxford: Oxford University Press.

Maslow, A. (1943). A theory of human motivation. Psychological Review, 50 (4), 370-396.

Ng, Y.-K., \& Ho, L. (2006). Introduction: Happiness as the only ultimate objective of public policy. In Y.-K. Ng, \& L. Ho. Happiness and public policy: Theory, case studies and implications (pp. 1-16). Houndmills: Palgrave Macmillan.

Norberg, J. (2005). The scientist's pursuit of happiness. Policy (21), 9-13.

Parker, G. (2000). Classifying depression: Should paradigms lost be regained? American Journal of Psychiatry, 157 (8), 1195-1203. http://www.ncbi.nlm.nih.gov/pubmed/10910777

Paykel, E., Hart, D., \& Priest, R. (1998). Changes in public attitudes to depression during the Defeat Depression campaign. British Journal of Psychiatry, 173 (6), 519-522. http://www.ncbi.nlm.nih.gov/pubmed/9926082

Peer, L. (1992). The practice of opinion polling as a disciplinary mechanism: A Foucauldian perspective. International Journal of Public Opinion Research, 4 (3), 230-242.

Philip, B. (2009). Analysing the politics of self-help books on depression. Journal of Sociology, 45 (2), 151-168. doi: $10.1177 / 1440783309103343$

Pratt, L., Brody, D., \& Gu, Q. (2011). Antidepressant use in persons aged 12 and over: United States, 2005-2008. Hyattsville MD: National Centre for Health Statistics. http://www.cdc.gov/nchs/data/databriefs/db76.htm

Radcliff, B. (2001). Politics, markets, and life satisfaction: The political economy of human happiness. The American Political Science Review, 95 (4), 939-952.

Ridge, C., Rice, T., \& Cherry, M. (2009). The causal link between happiness and democratic welfare regimes. In A. K. Dutt, \& B. Radcliff, Happiness, economics and politics (pp. 271-284). Cheltenham: Edward Elgar.

Robbins, L. (2008). The nature and significance of economic science. In D. M. Hausman, the philosophy of economics: An anthology (pp. 73-99). Cambridge: Cambridge University Press.

Rogers, C. R. (1947). Some observations on the organization of personality. American Psychologist, 2 (9), 358-368.

Ruddick, S. (2010). The politics of affect: Spinoza in the work of Negri and Deleuze. Theory, Culture \& Society, 27 (4), 21-45. doi: 10.1177/0263276410372235

Samuelson, P. A. (1948). consumption theory in terms of revealed preference. Economica, 15 (60), 243-253.

Scitovsky, T. (1976). The joyless economy: An inquiry into human satisfaction and consumer dissatisfaction. New York: Oxford University Press. 
Secretary-General of the United Nations. (2013, April 2). International Day of Happiness. Retrieved August 1, 2013, from United Nations: http://www.un.org/News/Press/docs/2012/sgsm14204.doc.htm

Seligman, M. E., \& Csikszentmihalyi, M. (2000). Positive psychology: An introduction. American Psychologist, 55 (1), 5-14. doi: 10.1037//0003-066X.55.1.5

Skinner, B. (1971). Beyond freedom and dignity. Indianapolis: Hackett Publishing.

Spinoza, B. d. (1996). Ethics. London: Penguin.

Szasz, T. S. (1960). The myth of mental illness. American Psychologist, 15 (2), 113-118.

Tribe, K. (2008). Happiness: What's the use? Economy \& Society, 37 (3), 460-468. doi: $10.1080 / 03085140802172730$

Veenhoven, R. (2004). Happiness as a public policy aim: The greatest happiness principle. In L. P.A., \& S. Joseph, Positive psychology in practice (pp. 658-678). Hoboken: John Wiley.

Wakefield, J. C., \& First, M. B. (2012). Validity of the bereavement exclusion to major depression: Does the empirical evidence support the proposal to eliminate the exclusion in DSM-5? World Psychiatry, 11 (1), 3-10. http://www.ncbi.nlm.nih.gov/pubmed/22294996

Waring, M. (1989). If women counted: A new feminist economics. London: Macmillan.

Waterman, A. S. (2013). The humanistic psychology-positive psychology divide: Contrasts in philosophical foundations. American Psychologist, 68 (3), 124-133. doi: 10.1037/a0032168

Watson, J. B. (1913). Psychology as the behaviorist views it. Psychological Review, 20 (2), 158-177

Whitaker, R. (2010). Anatomy of an epidemic: Magic bullets, psychiatric drugs, and the astonishing rise of mental illness in America. New York: Crown.

Williams, C. (2010). Affective processes without a subject: Rethinking the relation between subjectivity and affect with Spinoza. Subjectivity, 3 (3), 245-262. doi: 10.1057/sub.2010.15

World Health Organization (2008). The global burden of disease: 2004 Update. Geneva: WHO. http://www.who.int/healthinfo/global_burden_disease/2004_report_update/en/ 